Article

\title{
Jesus "The Way" According to Origen and Marcellus: Confronting Two Patristic Traditions
}

\author{
Samuel Fernández (iD
}

check for

updates

Citation: Fernández, Samuel. 2021. Jesus "The Way" According to Origen and Marcellus: Confronting Two Patristic Traditions. Religions 12: 452. https://doi.org/10.3390/rel12060452

Academic Editor: Paul Anderson

Received: 29 April 2021

Accepted: 15 June 2021

Published: 18 June 2021

Publisher's Note: MDPI stays neutral with regard to jurisdictional claims in published maps and institutional affiliations.

Copyright: (C) 2021 by the author. Licensee MDPI, Basel, Switzerland. This article is an open access article distributed under the terms and conditions of the Creative Commons Attribution (CC BY) license (https:/ / creativecommons.org/licenses/by/ $4.0 /)$.
Faculty of Theology, Pontificia Universidad Católica de Chile, Santiago 7820436, Chile; sfernane@uc.cl

\begin{abstract}
The article aims to examine and compare the evangelic title of Jesus the Way (John 14:6) in two Christian authors who belonged to two opposing theological traditions, namely, Origen of Alexandria and Marcellus of Ancyra. This comparison, based on original texts, aims not only to show the differences between these two patristic traditions, but rather to identify some common traits that belong to the core of Christian faith. Thus, Origen of Alexandria and Marcellus of Ancyra, two very dissimilar Christian authors, were of the same mind in confessing that only if the Son of God became fully human, could he be the Way for humankind towards the Father.
\end{abstract}

Keywords: Origen of Alexandria; Marcellus of Ancyra; Christology; Jesus the Way

\section{Introduction}

Spirituality is a modern expression, unknown in the patristic period. However, ancient patristic authors sought for a fulfilled and authentic Christian existence, and also reflected on how to follow Jesus of Nazareth. They used various perspectives, approaches and metaphors to understand and explain what is called Christian spirituality today. One of these metaphors was the evangelic image of Jesus the Way (John 14:6). This article therefore aims to examine and compare this evangelic title in two Christian authors who belonged to two opposing theological traditions, namely, Origen of Alexandria and Marcellus of Ancyra. In general terms, the main features of the Alexandrian tradition were the subsistence of the Logos (Logostheologie), "high Christology" and Platonic spiritualism. The Asiatic Christian tradition, represented by Marcellus, was characterized by the Monarchian tendency, a "low Christology" and Stoic materialism. In this context, the terms "Alexandrian" and "Asiatic" must be understood culturally rather than geographically (Simonetti 1973b; Ayres 2004, pp. 41-84). However, this comparison aims not only to show the differences between these two Christological traditions, but rather to identify some common traits that belong to the core of Christian faith.

\section{Jesus the Way According to Origen}

Origen of Alexandria (+256) was at the same time an exegete, theologian and a master of Christian life (Martens 2012). When he was in Alexandria, before his transfer to Caesarea in Palestine, he wrote On First Principles (Princ.) and the first part of his Commentary on John (Com. Jo.). These two works contain crucial elements for reconstructing his Christology and his idea of Jesus the Way. One of the distinctive features of Origen's Christology is his reflection on the various names of the Son of God, the well-known doctrine of the

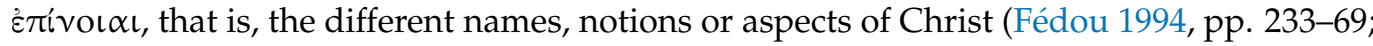
Jacobsen 2015, pp. 273-77). Hence, to study Jesus as the Way according to Origen, one should set this title in the complex of the other aspects. The Commentary on John offers the foundation of this doctrine:

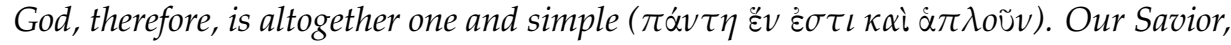
however, because of the many things ( $\delta i \grave{\alpha} \tau \grave{\alpha} \pi \circ \lambda \lambda \dot{\alpha})$, since God 'set' him 'forth as a

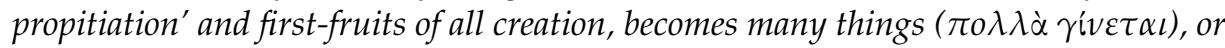


perhaps even all these things ( $\kappa \alpha i ̀ \dot{\imath} \alpha \alpha \pi \dot{\alpha} \nu \tau \alpha \tau \alpha \tilde{\tau} \tau \alpha$ ), as the whole creation which can be made free needs him. (Com. Jo. 1.20.119, Heine 1989, p. 58)

The above passage is very rich. On the one hand, it contrasts God's simplicity with the Savior's multiplicity. On the other hand, it affirms that this multiplicity is related to the needs of the creatures. Some aspects belong to the Son eternally, independently of the creatures, such as Wisdom, Logos, Life and Light; others, in turn, depend on the creatures, such as Light of men and Firstborn from the dead:

And it is possible to perceive a similar thing also in the case of him being the firstborn [from] the dead. For if, by way of supposition, the woman had not been deceived and Adam had not fallen into sin, but the man created for incorruption had grasped incorruption, he would have neither descended 'into the dust of death' nor died since there would have been no sin for which he had to die because of his love for men. And if he had not done these things, he would not have become the 'firstborn from the dead'. (Com. Jo. 1.20.121, Heine 1989, pp. 58-59)

Hence, he is Wisdom and Logos eternally, but he becomes "Resurrection" or "Shepherd" for the purpose of salvation. According to Origen's Christological frame, then, with a view to creation, the only-begotten Son of God, the Wisdom, was "created," not as such, but as "the beginning of the ways of God for his works," (Prov 8:22) because the models of the entire creation were created within the eternal Wisdom (Princ. 1.2.2). This is the first occurrence of the "way" related to the Son in Origen's presentation of the history of salvation. At this point, the eternal Logos is the beginning of the "Ways" of God. Although Origen quoted Proverbs 8:22 several times in On First Principles, he focused on the problematic verb "create" $(\kappa \tau i \zeta \omega)$ rather than the meaning of the "Ways" of God:

Now, in the same way in which we have understood that Wisdom is the beginning of the ways of God, and is said to be created, that is, forming beforehand and containing within herself the species and reasons of the whole creation, in the same manner must she be understood to be the Word of God, as she discloses to all other beings, that is, to the entire creation, the reason of the mysteries and secrets which are contained within the Wisdom of God. (Princ. 1.2.3, Behr 2017, p. 43)

As previously stated, the only-begotten Son of God becomes what is needed by the creatures. Therefore, when the rational beings, who were mutable, fell away from their original communion with God, "the Logos and Wisdom of God became the Way" (Princ. 1.2.4). Since rational creatures moved away from God, they needed the Logos as the way back to God the Father:

The [Wisdom] is called the 'Way' because she leads to the Father those who walk along her. Whatever, therefore, we have said of the Wisdom of God will appropriately be applied and understood also in the case of saying that the Son of God is the Life and that he is the Logos and that he is the Way and that he is the Truth, and that he is the Resurrection; for all these titles are named from his works and his powers. (Princ. 1.2.4, Behr 2017, p. 45)

When the creatures sinned, they went far from God the Father and, therefore, they needed the Logos as the Life, the Truth, the Resurrection and the Way. At this stage, the one who became the Way was the eternal Logos of God, not the incarnate one. However, in the next step of the history of salvation, the topic of the "Way" is related to the incarnation. To explain the Christological meaning of the biblical words "the express figure of his substance" (Heb 1:3), Origen provides the example of the two statues: one of such magnitude that cannot be seen by anyone, and another statue made similar to the former in every respect, but not in its immensity of size, so that those who were unable to see the enormous one could see the former upon seeing the latter:

By some such likeness, the Son of God emptying himself of equality with the Father (Phil 2:7) and showing us the way by which we may know him, becomes 'the express figure of his substance' (Heb 1:3), so that we, who were unable to look upon the glory of the pure light while it remained in the magnitude of his divinity, may, by his becoming for us the 
splendor, obtain the way of beholding the divine light through looking upon the splendor.

(Princ. 1.2.8, Behr 2017, p. 53)

The expression "emptying himself" (Phil 2:7) indicates that, this time, Origen was thinking on the incarnation. On this occasion, the "Way" is no longer the Logos as such, but the Logos made human. The Son of God, because of the incarnation, became the Way since he made the divine glory accessible for the rational beings, who were unable to look upon the glory of God directly. The comparison of the two statues, then, affirms that the Logos made man became the Way of revelation. The Logos becomes (efficitur) "the express figure of God's substance" for us (nobis) in order to reveal to rational creatures the eternal Father.

The Logos, then, became the Way on account of revelation. However, revelation was not the only theological function of the incarnation. The eternal Son also became an example for humankind and, therefore, a guide for the Way. Origen affirms that "for the sake of mankind" the Son of God assumed "not only a human body, as some suppose, but also a soul" (Princ. 4.4.4). Since Alexandrian anthropology revolves around the soul, stressing that the Logos assumed a soul means for Origen that the Son of God became fully human. Only Jesus, the Logos made fully human, can be an example and a guide, that is, the Way for humanity:

For this reason Christ is put forward as an example (exemplum) to all believers, because just as he always, even before he knew evil at all, chose the good and loved righteousness and hated iniquity, and therefore 'God anointed him with the oil of gladness' (Ps 44:8), so also each one ought, after a lapse or transgression, to cleanse himself from the blemishes by the example put forward, and, having him as the guide of the journey (itineris dux) proceed along the arduous path of virtue. (Princ. 4.4.4, Behr 2017, p. 571)

This time, it is possible to speak properly about Jesus, the Son of God made fully

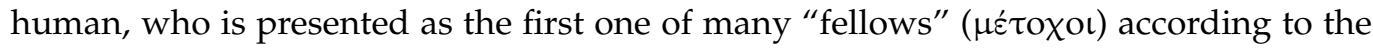
Christian interpretation of Ps 44:8 (see Princ. 2.6.4). This expression has an ecclesial dimension. Hence, since he is a fellow, he can be the example for mankind. Jesus is the Way not only because he reveals the Way, but because he is the leader of the journey (itineris $d u x$, possibly $\delta \delta \eta \gamma o ́ \varsigma)$. Hence, in Origen's view, Jesus not only shows the Way but also walks it. Therefore, the very life of Jesus is an example for mankind (Princ. 4.4.4). In the same passage, the master of Alexandria further developed the metaphor of the Way by quoting: "He who says that he believes in Christ ought himself to walk just as he walked" (1 John 2:6). It is clear, then, that for Origen salvation was not just a matter of knowledge, as frequently repeated (Scott 2015, p. 41) but a way of life. In addition, the topic of the way has a Trinitarian character:

In those alone, I think, who already turn to better things and walk in the ways of Jesus Christ, that is, who are engaged in good actions and abide in God, is there the work of the Holy Spirit. (Princ. 1.3.5, Behr 2017, p. 75)

The one who walks in the ways of Jesus Christ, towards God, receives the assistance of the Holy Spirit. This is an expression of Origen's Trinitarian idea of participation: all the creatures that "are" participate in God who is "the One who is" (Ex 3:14). Only rational

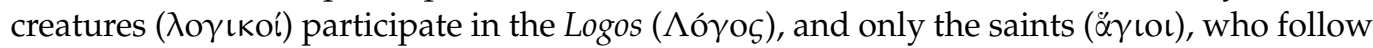
the Way of Jesus, participate in the Holy Spirit (Princ. 1.3.5-8). In addition, the topic of Jesus as the Way echoes the traditional theme of the two ways (Princ. 3.2.4), which, in turn, is related to the doctrine of free will, one of his distinctive Origenian topics (Princ. 3.1; Fürst 2014, pp. 460-567).

Finally, this doctrine also has eschatological implications. In fact, the master of Alexandria affirmed that "in the last times, when the end of the world was already imminent," the eternal Son "emptied himself and taking the form of a servant," (Phil 2:7) restored human obedience to God: 
As the [Son of God] had come, then, to restore the discipline not only of ruling and reigning, but also of obeying, as we have said, fulfilling in himself first what he desired to be fulfilled by others, becoming obedient to the Father not only unto the death of the cross but also in the consummation of the age, by embracing in himself all whom he subjects to the Father and who come to salvation through him, he himself, with them and in them, is also said to be subject to the Father. (Princ. 3.5.6, Behr 2017, p. 435)

Although the term "way" is not explicit, the notion is certainly present. Again, it is not the Logos as such, but the man Jesus who walks the way of obedience to God the Father. Again, it is not just matter of knowledge: the Son of God made man fulfill in himself first what he desires to be fulfilled by others (in semet ipso prius complens quod ab aliis volebat impleri). It is possible for humans to walk the path of obedience to God because Jesus, the man, walked it first. It is only Jesus, the Logos made man, fully divine and fully human, who can be an example. As the eternal Son of God, he is able to walk the way towards the Father; as the Son made human, he is able to be followed by humans. Since he becomes man, he is a followable leader of the journey of humankind, the one who fulfills in himself first the destiny of humankind (Fernández 2019, pp. 563-72). These notions lie behind what, in modern times, is called the spirituality of following Jesus.

\section{Jesus the Way According to Marcellus}

Marcellus, bishop of Ancyra in Galatia (+374), played a significant role during the so-called Arian controversy of the fourth century (Lienhard 1999; Parvis 2006). He sharply opposed Arius and his fellows and supported Nicaea and Athanasius. The bishop of Ancyra was a controversial figure, praised by Pope Julius and the synod of Serdica (343), as well as condemned by Eusebius of Caesarea and the synod of Constantinople (336). Marcellus was, on the one hand, an heir of Asia Minor's theological tradition and, on the other, a creative theologian. As representative of Asia Minor's theology, he echoed Irenaeus' theology, valued the humanity of Christ and insisted in the unity of God, yet in an original fashion. Although Marcellus used some Origenian statements against his opponents (Ramelli 2011), he draws little from him (Ayres 2004, p. 63). Much of his writings are lost: Marcellus' letter to Julius of Rome (Ep.) is transmitted by Epiphanius (Haer. 72,23.); Eusebius of Caesarea, in his polemic works, preserved more than 120 fragments of a significant theological treatise against the fellows of Arius, and these fragments (Fr.) are quoted according to Vinzent's numbering (Vinzent 1997); and a small pseudonymous tract, De sancta ecclesia (SE.), has been attributed to him with solid reasons (Logan 2000, pp. 81-112). Finally, a number of pseudo-Athanasian works have been attributed to him, but none of these attributions have found acceptance among scholars (Simonetti 1973a, pp. 313-29).

To understand the topic of Jesus the Way according to Marcellus, it is necessary to set it in the frame of his view of the history of salvation. The Galatian bishop believed that in the very beginning God was alone and the logos was not a subsistent being but was in God as a divine faculty: "before the fashioning of all, there was a certain silence, as one might expect, since the logos was in God ( $\varepsilon \vee \tau \widetilde{\omega} \theta \varepsilon \widetilde{\varphi})^{\prime \prime}$ (Fr. 76; Fernández 2018, pp. 107-20). Since the $\log o s$ was not a personal entity, I do not write it with capital letter. At the beginning, then, the $\log 0$ s was nothing but $\log o s(F r .3 ; 5 ; 7 ; 65 ; 94 ; E p .2 .4)$. Eternally, it was not the Son, but reason of God $(\lambda o ́ \gamma 0 \varsigma)$. In line with these tenets, Marcellus interpreted the well-known verse of Proverbs 8:22, in an original manner:

Therefore, as was fitting, when ancient things had passed in due season and all future things were going to become new through the newness of our Savior, Christ our Lord proclaimed through the prophet, 'The Lord created me as the beginning of his ways'. (Fr. 27, McCarthy-Spoerl and Vinzent 2017, p. 285) 
Previous Christian traditions had regularly referred to Proverbs 8:22 as the pre-cosmic origin of the Son of God. In turn, Marcellus rejected this interpretation and applied the biblical verse to the incarnation (this interpretation was followed by Athanasius of Alexandria, see C. Ar. 2,44-46; 2,50-55; 2,61,1-2; 2,66,1; 2,67,2; 2,71,2). The following fragment is explicit:

Accordingly, the 'creation' refers to the fact that he is a man. For this reason he says, 'The Lord created me as the beginning of his ways for his works' (Prov 8:22); 'created me,' that is, through the Virgin Mary, through whom God chose to unite the human flesh to his own logos. (Fr. 28, McCarthy-Spoerl and Vinzent 2017, p. 138)

And again:

We should closely investigate this passage, which was stated in proverbial fashion: 'The Lord created me as the beginning of his ways' (Prov 8:22). For the Lord our God, having made that which did not exist previously, truly created. For he created not the existing flesh, which the logos assumed, but the non-existent flesh. (Fr. 29, McCarthy-Spoerl and Vinzent 2017, p. 284)

Only when the logos became flesh (John 1:14) did it become "the beginning of his ways for his works" (Prov 8:22). In eternity, the logos was nothing but logos, whereas, "after the assumption of the flesh the [logos] is proclaimed both Christ and Jesus, as well as Life and Way and Day and Resurrection and Door and Bread" (Fr. 3). It is noteworthy that Marcellus used "flesh" as a synonym of the whole human being (Fr. 11; 15; 61). Thus, not the eternal logos as such, but the incarnated one became the Way and the beginning of God's ways. Another fragment explains the meaning of this last expression: "For this one became way of piety for us who were going to walk justly, a beginning of all the ways after these" (Fr. 30, McCarthy-Spoerl and Vinzent 2017, p. 286).

Again, "this one" was not the eternal logos itself, but the human being assumed by the logos. This man, namely, Jesus, was the way of piety for those who were going to walk justly. It is possible for humans to walk this way of piety because it was walked by the man Jesus first. Marcellus further clarified the meaning of the biblical verse:

Therefore, [the prophet] says, 'He created me as the beginning of his ways for his works' (Prov 8:22). Of what sort of works, however, does he speak? The Savior says about them, 'My father is working still, and I am working' (John 5:17). And again he says, 'I have accomplished the work which you gave me to do'. (Fr. 32, McCarthy-Spoerl and Vinzent 2017, p. 288)

Consequently, "the ways for his works" refer the very works of, so to say, the historical Jesus. The life and works of Jesus—not only his death and resurrection-have a salvific meaning for believers. He is the Way for Christians by virtue of his humanity. As a human, Jesus really is able of being followed by humans. What Jesus has done is capable of being done by other human being, since he was a real man in communion with the eternal logos. This Christology echoes Irenaeus' notorious statement: “The Word of God, our Lord Jesus Christ, through his immeasurable love, became what we are, that he might bring us to be even what he is himself" (Haer. 5. preface). In addition, a fragment that speaks about the "evil way of those who are not Christian" (Fr. 118) suggests that Marcellus knew, as Origen did, the traditional theme of the two ways.

In addition, the bishop of Ancyra developed the ecclesial dimension of this doctrine. The verse of Proverbs 8:22 speaks about "ways", in plural, and about "the beginning of ways". Jesus, then, according to Marcellus, was the Way, which was the beginning of other ways. On this basis, the bishop explained the contents of the biblical verse:

The [prophet] rightly said that the Lord our Savior was a 'beginning of ways' because he also became a beginning of the other ways (after the first way), which we have come to possess, revealing the traditions through the holy apostles who, 'with exalted proclamation' (Prov 9:3) according to the prophecy, proclaimed to us this new mystery. (Fr. 31, McCarthy-Spoerl and Vinzent 2017, p. 286) 
Hence, Jesus was the first of many ways because the leaders of the Church, namely, the apostles, their disciples and the bishops continued the works of Jesus (SE. 3). The man Jesus was the departing point and the foundation of this succession. Marcellus had a deep sense of tradition, which is another feature that echoes Irenaeus' thought. This tradition, however, will have an end when the last time arrives. The bishop of Ancyra believed that the end should be similar to the beginning, and that Christ's kingdom did not begin with the eternal logos but with the man assumed by the logos; hence, since Christ's kingdom had a beginning no more than 400 years ago, it should have an end (Fr. 103; 106). The following fragment outlines the whole logos' journey, from the beginning to the end:

God is one and the logos of God went forth from the Father, so that all things might come to be through him (John 1:3), but after the time of judgment, the restoration of all things, and the destruction of all opposing activity, 'Then he will be subjected to him who put all things under him' (1 Cor 15:28) to [his] God and Father, so that in this way the logos might be in God, just as he also was previously before the cosmos existed. (Fr. 109, McCarthy-Spoerl and Vinzent 2017, p. 132)

In line with his theology, Marcellus proposed that since the logos began to be "the Way", when the economy of the flesh started, the logos will no longer be "the Way" when the economy of the flesh concludes. Since the mediating function of the logos had a beginning, it will have an end. In line with his emphasis on the unity of God, at the end, the logos will be in God as a divine faculty, just as he was before creation.

\section{Confronting Two Traditions}

At first glance, both the authors were opposed on almost all issues. Origen represented the Alexandrian tradition and culture, had a positive view of philosophy and focused his anthropology on the human soul, whereas Marcellus represented the tradition of Asia Minor, had a negative view of philosophy and focused his anthropology on the human flesh. Origen's theology emphasized the alterity of the Logos regarding the Father and, therefore, affirmed that the Logos had his own hypostasis; in turn, Marcellus highlighted the unity of God and, thus, rejected the theology of the two or three hypostases in God. However, a close examination of their doctrines shows that beyond their differences they share relevant theological points.

Origen supported that the Logos was generated as the only Son of God eternally; for Marcellus, in turn, the logos was a divine faculty eternally that became the Son of God in the incarnation. However, both the authors affirmed that the Logos was not "the Way" from the very beginning. According to Origen, the Logos became "the beginning of God's ways" in view of creation (Prov 8:22); in turn, Marcellus thought that this occurred when the logos became man. In addition, the "works" alluded to in Proverbs 8:22, according to the Alexandrian, were the works of creation, whereas for the bishop of Ancyra, they were the works Jesus performed during his earthly life (John 5:17). In addition, for Origen, the Logos as such became "the Way" when the creatures turned away from God; Marcellus instead thought that the logos became "the Way" only when he was born from Mary. According to both the authors, then, the Logos became the Way for the sake of creatures. Thus, they agreed that the Logos of God modified himself, so to say, according to the needs of human beings. Correspondingly, Origen declared that even before the incarnation the Logos was the image of the invisible God and the first-born of all creation (Col 1:5), while Marcellus affirmed that it was not the logos as such, but Jesus, the visible man united with the logos, who was the image of the invisible God and the first-born of all creation (Col 1:5).

From different anthropological departing points, both the authors stressed that the Son of God needed to become fully human in order to be "the Way" for humankind and to achieve his mediation role. Both the Christian writers stressed the fullness of Jesus' humanity differently: While Origen affirmed that Logos assumed not only a body but also a human soul, Marcellus insisted that the logos assumed a human "flesh". In conformity with these statements, both theologians supported that it was possible to follow Jesus just because he was fully human; that is to say, only in virtue of his humanity the Son of God 
became fully "the Way" for humankind. In fact, it was not possible to follow the Logos as such. In addition, both Christian authors knew the traditional theme of the two ways, and both supported the ecclesial dimension of Jesus the Way; since Origen presented Jesus as the first of many fellows, Marcellus explicitly affirmed that Jesus was the beginning of the many ways of the apostles and their successors. At the last step of the history of salvation, there is a difference between Origen and Marcellus. The master of Alexandria affirmed that the Logos' mediating function will continue in the afterlife, whereas the bishop of Ancyra supposed that after the final judgment, the logos will no longer be mediator and, therefore, the Way.

In summary, Origen of Alexandria and Marcellus of Ancyra, two very dissimilar Christian authors, with different theological, philosophical and cultural backgrounds, were of the same mind in confessing that only if the Son of God became fully human could he be the Way for humankind towards the Father. Hence, the patristic topic of Jesus the Way offers an exceptional window for visualizing what today we call the spirituality of Jesus. Towards the end of the fourth century, the Nicene homoousios took hold and became the hallmark of orthodoxy (Anderson 2018, pp. 85-88). In this context, as a reaction against Arianism, a one-sided insistence on the divinity of Christ emerged. This unilateral anti-Arian spirit lies behind the successive Christological heresies that tended to exalt Christ's divinity and to weaken or segregate his humanity. This is one of the factors that explain the hidden and persistent Monophysite tendency of the later Christology. For that reason, these Christian theologians of the formative period, such as Origen and Marcellus, although belonging to opposing traditions, are permanent witnesses of the Christian faith in the full humanity of the Son of God. According to this common Christology, only a fully human Jesus enables humanity to walk the spiritual path embodied in the life and ministry of Jesus as the Way.

Funding: This research was funded by Fondecyt Regular, 1190025 (2019-2021).

Institutional Review Board Statement: Not applicable.

Informed Consent Statement: Not applicable.

Data Availability Statement: Not applicable.

Conflicts of Interest: The author declares no conflict of interest.

\section{References}

Anderson, Paul N. 2018. The Johannine Riddles and their Place in the Development of Trinitarian Theology. In The Bible and Early Trinitarian Theology. Edited by Christopher A. Beeley and Mark E. Weedman. Washington, DC: The Catholic University of America Press, pp. 84-108.

Ayres, Lewis. 2004. Nicaea and Its Legacy: An Approach to Fourth-Century Trinitarian Theology. Oxford: Oxford University Press.

Behr, John. 2017. Origen of Alexandria, On First Principles. Oxford: Oxford University Press.

Fédou, Michel. 1994. La Sagesse et le monde: Essai sur la christologie d'Origène. Paris: Desclée.

Fernández, Samuel. 2018. Marcellus and Eusebius on the Gospel of John in 'De ecclesiastica theologia'. Annali di Storia dell'Esegesi 35: 107-20.

Fernández, Samuel. 2019. That Man Who Appeared in Judaea (Prin II,6,2): The Soteriological Function of the Humanity of the Son of God according to Origen's 'De principiis'. In Origeniana Duodecima: Origen's Legacy in the Holy Land-A Tale of Three Cities: Jerusalem, Caesarea and Bethlehem. Edited by Bruria Bitton-Ashkelony, Hillel Newman, Lorenzo Perrone, 'Oded 'Ir-shai and Aryeh Kofski. Leuven: Peeters, pp. 563-72.

Fürst, Alfons. 2014. Origenes. In Reallexikon für Antike und Christentum. Stuttgart: Anton Hiersemann Verlag, 26, col. pp. 460-567.

Heine, Ronald E. 1989. Origen of Alexandria, Commentary on the Gospel According to John. Washington, DC: Catholic University of America.

Jacobsen, Anders-Christian. 2015. Christ-The Teacher of Salvation: A Study on Origen's Christology and Soteriology. Münster: Aschendorff. Lienhard, Joseph. 1999. Contra Marcellum: Marcellus of Ancyra and Fourth-Century Theology. Washington, DC: Catholic University of America.

Logan, Alastair H. B. 2000. Marcellus of Ancyra (Pseudo-Anthimus), 'On the Holy Church': Text, Translation and Commentary. The Journal of Theological Studies n.s. 51: 81-112. [CrossRef]

Martens, Peter W. 2012. Origen and Scripture: The Contours of the Exegetical Life. Oxford: Oxford University Press. 
McCarthy-Spoerl, Kelly, and Markus Vinzent. 2017. Eusebius of Caesarea, Against Marcellus and On Ecclesiastical Theology. Washington, DC: Catholic University of America.

Parvis, Sara. 2006. Marcellus of Ancyra and the Lost Years of the Arian Controversy. Oxford: Oxford University Press.

Ramelli, Ilaria L. E. 2011. Origen's Anti-Subordinationism and its Heritage in the Nicene and Cappadocian Line. Vigiliae Christianae 65: 21-49. [CrossRef]

Scott, Mark S. M. 2015. Journey Back to God: Origen on the Problem of Evil. Oxford: Oxford University Press.

Simonetti, Manlio. 1973a. Su alcune opere attribuite di recente a Marcello d'Ancira. Rivista di Storia e Letteratura Religiosa 9: 313-29.

Simonetti, Manlio. 1973b. Teologia alessandrina e teologia asiatica al concilio di Nicea. Augustinianum 13: 369-98. [CrossRef]

Vinzent, Markus. 1997. Markell von Ankyra, Die Fragmente. Der Brief an Julius von Rom. Leiden: Brill. 